\title{
Contested spaces? The use of place concepts to communicate visions for peri-urban areas
}

Forthcoming: European Planning Studies

Ir J. (Judith) Westerink (corresponding author)

Alterra Wageningen UR

PO Box 47

6700 AA Wageningen, The Netherlands

Tel: +31-(0)317-481587

Fax: +31-(0)317-419000

Judith.westerink@wur.nl

Dr. A. (Arnoud) Lagendijk

Nijmegen School of Management

Department of Human Geography and Spatial Planning

Radboud University Nijmegen

PO Box 9108

6500 HK Nijmegen, The Netherlands

Tel: +31-(0)24-3616204

A.Lagendijk@,ru.nl

Dr. S. (Stefanie) Dühr

Nijmegen School of Management

Radboud University Nijmegen

PO Box 9108

6500 HK Nijmegen, The Netherlands

Tel.: +31-(0)24-3613051

s.duhr@,fm.ru.nl

Drs. P.D. (Pat) van der Jagt

Alterra Wageningen UR

PO Box 47

6700 AA Wageningen, The Netherlands

Tel: +31-(0)317-481844

Pat.vanderjagt@wur.nl

Ir J. (Annet) Kempenaar

Alterra Wageningen UR

PO Box 47

6700 AA Wageningen, The Netherlands

Tel: +31-(0)317-484580

Annet.kempenaar@wur.nl 


\begin{abstract}
In Dutch planning, there has always been an important role for spatial concepts. Their role has arguably changed with the recent decentralisation of planning to the regional and local level. At the national level, guiding concepts of a more procedural nature have replaced the more substantive and place-based spatial concepts, leaving more room for regional and local interpretation. At the regional and local level, spatial concepts are still in use, but this seems to be in a more communicative, negotiating and developing role than before. In this paper, we analyse how place concepts are used to exercise power, mobilize resources and frame meaning over the use of the peri-urban areas, in the changing Dutch planning context. This paper focuses on two competing place concepts for overlapping green urban fringe areas in The Hague Region, which have been promoted by different actor constellations and which represent different visions about the meaning of these peri-urban areas. The case study allows conclusions about the changing role of spatial concepts in Dutch spatial planning.
\end{abstract}




\section{Introduction}

Peri-urban areas are clear examples of the complexity of contemporary land use planning (Nilsson et al., 2008). One of the underlying reasons behind this complexity is the unclear meaning of these areas: are they urban or are they rural? Are they a platform for dynamics or are they assets to be preserved? Are they a production or a consumption landscape? Planning in many Western European countries, including the Netherlands, is increasingly an arena that is accessible for many parties, governmental and non-governmental, and where the exchange of views plays an increasing role. In policy making for peri-urban areas, we see that visions are communicated from different angles. Place concepts present an important repertoire used in these visions. Place concepts express through words and images how people look at the meaning, function and intended spatial organisation of an area (see also Zonneveld, 2005).

In this paper, we look at two competing place concepts for overlapping peri-urban areas in The Hague Region, The Netherlands, to gain insight into the role of such concepts in contemporary Dutch planning practice. Our overall focus of the analysis is to explore how these place concepts are used to exercise power, mobilize recourses and frame meaning over the use of peri-urban areas, and how this relates to the changing planning culture and practice in the Netherlands. Peri-urban areas are particular interesting for this inquiry. Their position in between 'proper' urban and rural areas has brought about a wide variety of viewpoints on their meaning and development, ranging from the extremes of consumption and leisure areas to agricultural production landscapes (Buijs et al., 2006). We will discuss how the changing planning context in The Netherlands has changed the role and the use of place concepts in our case studies. 
Much of the empirical material for this paper was derived from the case study of The Hague Region in the European 6th Framework research project PLUREL (Peri-urban Land Use Relationships). Within this integrated project peri-urban land use relations were studied in general (Nilsson et al., 2008), but the case study research on which this paper draws focussed in particular on planning and governance strategies for periurban areas, by means of document study, interviews and action research (Aalbers \& Van Dijk, 2007). The already available material on the two case study areas (see Aalbers et al., 2009) was for this paper supplemented with interviews with the project officer of the Land van Wijk en Wouden area committee (which is the institution promoting one of the competing visions) (26 March 2009) and an officer from South Holland Province (the higher-level authority for the two initiatives) (13 Oct 2010). These extra interviews were done to get more specific details about the initiatives and to follow their development.

This paper is structured as follows. First, we will discuss the change in Dutch planning culture and practice from a top-down and centralized system with use of substantive spatial concepts to a more decentralized system with a more negotiating form of governance in which guiding quality concepts are used. In the following section, we conceptualize the role of place concepts in spatial planning based on theoretical approaches on spatial frames, metaphors and power in planning. This theoretical framework will guide the analysis of our empirical cases in The Hague region. We conclude with general observations on the use of place concepts in periurban planning, the use of substantive and procedural spatial concepts, and their possible role in future. 


\section{Changes in the Dutch planning culture and practice}

The Netherlands present a peculiar case in which a centralised and comprehensive planning ambition is matched by a, in procedural-legal terms, decentralised system of spatial governance (Wolsink, 2003). One reason why for many years substantive spatial planning concepts (such as the 'Green Heart'), and more recently also procedural planning concepts (such as 'spatial quality' and 'preservation through development') have served such an important role is because they provided a core vehicle for the central state to cascade down core planning ambitions via the provincial-regional to the local-municipal level.

In the Dutch planning system of the past decades, often described as a conceptual paradise, ample use has been made of spatial concepts and spatial metaphor to communicate the key characteristics of a territory and to frame proposals for its future use (Dühr, 2007). Some of the best-known Dutch planning concepts, the 'Green Heart', 'Bufferzones' and the 'Randstad' have already been introduced in the 1950s (Rijksdienst voor het Nationale Plan, 1958) and have proven highly durable. The 'Green Heart' refers to a (semi-)open space that is surrounded by the 'City Ring' ('Randstad') of Amsterdam, Utrecht, Rotterdam and The Hague. The Bufferzones refer to the green space between the Randstad cities to distinguish them from each other (see Figure 1). Both the concepts Green Heart and Bufferzones served to provide the Randstad urbanites with sufficient recreational space and to set limits to urbanisation (Bervaes et al., 2002). In their essence, the concepts of the Randstad, the Green Heart and the Bufferzones have been argued to communicate the Dutch 'planning doctrine' (Faludi \& Van der Valk, 1994), namely the control of urban growth and the preservation of green open spaces in this densely populated country. 
Their durability and success in communicating key Dutch planning principles has been ascribed to their vagueness and focus on a limited number of key messages, which allowed them to muster support by being 'subtly emphasised, deemphasized or reinterpreted' (Hall, 1993: 44), thus allowing considerable flexibility in their interpretation over time and by different actors.

This vital communicative role and flexibility of spatial planning concepts should be understood in the context that much of Dutch planning policy is traditionally not 'implemented' but rather more subtly 'applied'. Whereas implementation refers to a regulatory approach which leads to directly measurable outcomes that conform to the expressed policy intentions, application means that policy ambitions, expressed through spatial concepts, are translated into planning policies and practices of other actors and at other levels of scale and being used in decision-making. In Dutch planning, this has generally been referred to as the 'performance' ("doorwerking") of planning concepts (Faludi, 2000; Mastop \& Faludi, 1997). In other words, in a country that has become known for its consensus-led approach to spatial planning, where the coordination between national, provincial and local levels is done not only through legal decisions but also through communication and negotiation, planning concepts have become an important instrument to shape 'the minds of actors involved in spatial development' (Faludi, 2001: 664).

In Dutch planning of the past decades, such 'performance' was assisted, moreover, by the centralised financial system which provided the central state with 'golden' strings of control (Faludi \& Van der Valk, 1994) and alignment with sectoral policy practices (notably housing and agriculture). In the post-war period, these conditions gave a vital impetus to the rise of a planning doctrine focused on containing urban growth in a country experiencing rapid population growth and fixated on maintaining a strong 
urban-rural divide, the demarcation of economic growth zones (initially in the periphery, later on in more central parts of the territory), and the expansion and integration of nature areas (Faludi \& Van der Valk, 1994).

While praised for its effectiveness and transparency for considerable time, the Dutch planning system was confronted with mounting critique from the 1980 s onwards. It was considered too blunt, lacking in local engagement and adaptation, and hence in effectiveness. Spatial planning was seen as being too slow, too reactive and hence in need for a more pro-active approach to spatial development. It was felt that a more decentralised, local programmatic approach was needed, which could take on board, in a more effective way, pressing economic, ecological and social needs, as expressed by local stakeholders, without a resort to overarching conceptualisations (Wolsink, 2003). Such an approach was also warranted given the more competitive, strategic setting in which coalitions of agents seek funding through competitive bidding for national and EU funding (the influence of EU funds on regionalisation was not limited to the Netherlands, see for instance (Bachtler \& McMaster, 2008). These concerns resulted in call for a shift in spatial governance from comprehensive integrated spatial planning to a focused integrating development planning (Wissink, 2000: 202). The aims and rationale of this new approach were detailed in an influential green paper, 'Spatial Development Policy', issued by the Dutch Scientific Council for Government Policy (WRR, 1998). A parallel development took place in environmental planning, in which a change was envisaged from 'command and control' to 'shared governance' (De Roo, 2003). Accompanying these trends, more emphasis was put on policy learning and integration as part of a move to more area-based development (Salet \& Woltjer, 2009). 
Against this background, the 1990s witnessed a proliferation of 'bottom up' ideas and initiatives of strategic spatial planning, as well as a 'sideways' involvement of other departments and agencies. This prompted what could be considered as new phase in the battle for spatial planning concepts (Zonneveld \& Verwest, 2005). The new initiatives included planning activities by city-regions and other spatial alliances (such as cross-border programmes), the establishment of centres of expertise in the field of spatial development (in relation to multiple land use, mobility, large projects etc), and a growing role of sectoral interventions. With respect to open space, the latter became manifest, in particular, in the eagerness of the Departments dealing with economic affairs and agriculture to express their views on the future of 'open space'. Economic interests had already become more prominent in national spatial planning from the 1970s onwards due to internationalisation pressures and recession. From the 1980s onwards the Department of Economic Affairs started to articulate its own spatial perspectives focusing on economic clusters and corridors, calling for more space for business estates (EZ, 1997). The Department of agriculture produced imaginative ideas on how to cross the urban-rural divide, for instance in the form of 'urban agriculture' (LNV, 1996). The Department of Spatial Planning, Housing and Environment, in its development of the national spatial master plans, took some of these ideas on board notably through an elaboration of the concept of 'urban networks'. However, while this entailed a shift in the meaning of 'urban' and 'rural', it did not mark a break with the ruling 'anti-sprawl' planning doctrine.

The way other actors than the national and local spatial planning departments and non-governmental actors began to promote alternative ideas on how to move beyond the urban-rural divide is relevant for our study. Such discussions in the Netherlands on peri-urban spaces are part of a general trend in European countries and are driven 
by processes of suburbanisation and counterurbanisation, supported by increased mobility and ICTs that reduce the importance of geographical proximity to urban areas as long as accessibility is ensured. Parallel to this development, shifts in rural economies from agricultural to other activities are resulting in considerable changes in rural areas, especially those close to larger cities and towns. In the 'European Spatial Development Perspective' (ESDP: CSD, 1999), this was communicated through a call for a 'new urban-rural relationship'. In response, a considerable debate ensued in many European countries, including the Netherlands, on appropriate new planning policy responses for a vast variety of types of peri-urban areas and the different interests that promote alternative ways on how to shape and use them.

In a formal sense, the move from top-down comprehensive to a more developmentoriented, more bottom-up approach to planning was facilitated by changes in Dutch planning legislation (Needham, 2005) and the most recent national spatial plan (Nota Ruimte: (VROM et al., 2004). The decentralisation of competences from the national to lower levels of government, as set out in the new Act on Spatial Development (WRO: VROM, 2008) implies that, with the exception of certain forms of land use of national concern (such as national parks and major infrastructural developments), strategic spatial planning should take place at the regional (provincial) and the municipal level. Provinces are given a more strategic role in the new Dutch planning system for coordinating municipalities, whereas local authorities have more authority in making land use decisions for their territories. Alongside this decentralisation of competences, there has been a shift from traditionally substantive spatial planning concepts towards more process-oriented concepts and guidance, as explained in more detail in the next section. A notable example of such a core process-oriented concept is 'spatial quality', intended as a framework through which the spatial-economic, 
social and ecological qualities of new developments can be assessed. After an initial discussion by the WRR in its 1998 report, 'spatial quality' was introduced in the Fourth National Spatial planning report and promoted to a core aim in its successor document, the 'Nota Ruimte' (Spaans \& Trip, 2010). It is defined though criteria relating to spatial and cultural diversity, economic and social functionalities, social equality, sustainability, attractiveness and 'human scale' (i.e. ensuring that space which is planned fits with citizens' demands and perceptions). Another example of a process-oriented concept is 'preservation through development' as introduced by the Department of Culture in its 'Nota Belvedere' (OCW et al., 1999; Reuselaars, 2003). The concept illustrates a shift in thinking from 'conservation' of landscape and heritage to integrating new functions and activities, as long as the 'quality' of the site as a whole would benefit. The other way around, making use of heritage value and place identity was considered to benefit spatial development. 'Belvédère areas', areas with a high heritage value were delineated to aid this approach.

These shifts in Dutch planning over the past years have provided considerable scope for new forms of knowledge production and use and for experimentation with new planning approaches. Importantly for this paper, they have also introduced major changes to the role and significance of regional and local planning. While regional and local planning actors have always enjoyed considerable autonomy, the former planning system and budgetary regime compelled them to apply the prevailing planning ambitions and concepts articulated in the national spatial plans. Within the new framework, the application of national spatial concepts, and indeed even the preparation of national spatial concepts, is arguably being eroded. However, as we will discuss in the following sections, the power of such concepts nonetheless seems 
to ensure their durability. We will examine to what extent, and in what manner, current Dutch local and regional planning processes continue to refer to these established planning concepts in preparing and drafting local/regional plans. In particular, we will consider to what extent their role may have changed, from one where they encapsulated the application of national planning 'doctrine', to a more flexible role of communication, negotiation and arbitration in local planning processes. The next section will provide a conceptual basis for this assessment.

\section{Conceptualising the role of place concepts in spatial planning}

As discussed above, in the Netherlands, as in other Western European countries, spatial planning has recently moved away from a top-down process of making strategic spatial plans and allocating land use to more decentralised and developmentoriented forms seeking to steer spatial development. While national policy objectives and guiding principles continue to be important for decision-making and influencing planning processes at provincial and local levels, they are now frequently accompanied by collaborative and bottom-up planning processes. Local authorities, as the key spatial planning actors at municipal level, are increasingly also engaged in collaborative strategic planning processes at the city-regional level, reflecting the increasing connections between urban and rural areas described in the previous section. Such forms of more collaborative non-statutory planning at city-regional level have also presented opportunities for a stronger engagement of non-governmental actors in discussions on spatial development. Peri-urban areas, where different interests over the use and development of space tend to collide, reflecting different perspectives on the rural past of such areas, questions of identity, and their possible future in relation to nearby cities, frequently appear to be the subject of such more 
pluralistic and collaborative planning processes. Depending on the viewpoint, periurban areas can be seen as what could be described as 'consumption spaces' (i.e. open space, a greenbelt or 'green lung', a recreation area, a residential area for the wealthy) or a 'production space' (i.e. used for farming or semi-rural economic activities), or as a combination of different functions. Whichever viewpoint is supported will engage different actors and lead to different discourses that bind these actors together and communicates their perspectives vis-à-vis those of other actors.

An important instrument for the articulation of ideas and discourses over spatial futures in communicative planning processes is spatial framing (see (Van den Brink, 2009). The process of framing has been defined as 'a way of selecting, organising, interpreting and making sense of a complex reality so as to provide guideposts for knowing, analysing, persuading and acting. A frame is a perspective from which an amorphous, ill-defined problematic situation can be made sense of and acted upon' (Rein \& Schön, 1986: 4). Frames also come with a guidance of which actions to take, invoking scripts and instruments drawn from the existing repertoire of planning tools and promoting certain development projects. As a result, framing plays a critical role in bridging the more general understanding of the principles of spatial planning as an institutional activity and the practices of spatial planning 'on the ground'.

How this bridging takes place, however, remains a difficult issue to assess. Looking in more detail into the process of communication and framing, some scholars have pointed at the way power is played out in local planning practices (see for example (Flyvbjerg, 1998; Richardson, 2006; Throgmorton, 2003). In Flyvbjerg's and Richardson's (2002: 47) words, 'communication is more typically characterised by non-rational rhetoric and maintenance of interests than by freedom from domination and consensus-seeking'. Richardson (2006:205) argues that many core arguments 
often hinge on what he calls 'thin simplifications' that are embedded in the supportive analytical accounts that produce smoothing 'facts' about a certain territory, the wider spatial environment and their spatiality. Powerful agents are often able to marginalize competing stories, encouraging 'planners to devise plans that are designed to persuade only the audiences that most matter to them' (Throgmorton, 2003: 127). As a result, frames are often bent to the interests and voices of the more powerful. Knowledge is produced, claims are made, and conclusions drawn in such a way that, while often alluding to rationalities based on objectivity and neutrality, they match specific political positions and interests.

Thus, as Flyvbjerg, Richardson, Throgmorton and others have argued, the significance of power should not only be read in terms of direct control and domination. Power also constitutes a key foundation of social relations and hence a major resource of collective action. Flyvbjerg and Richardson (2002: 50) contend that 'rationality is penetrated by power', meaning that power structures shape policy making and implementation, but also rationality itself, in the sense of what is acceptable and appropriate in and for a given situation and which information and knowledge is considered valid. What is more, power presents a 'resource' not only in the way it helps agents to mobilise and align other agents, but also in the way it is sedimented in metaphors, concepts, and frames. As germane to all discursive entities, the latter do not just present the direct outcomes of power struggles; they are the carriers of previous debates and struggles on what aims and purposes spatial planning should pursue. They provide the broad terms of reference of rationality, in which power structures are embedded, and through which planning actors set and articulate their positions. Just like planning actors and in addition to other expressions of power 
in communicative planning processes, frames, concepts and metaphors, thus, exert power themselves (see Schön \& Rein, 1994).

This perspective can shed light on the importance of spatial concepts and spatial metaphor in the communication of an area's value and potential, as has traditionally been the case in the comprehensive-integrated spatial planning system of the Netherlands. Because of the reliance of such systems on communication and deliberation, core questions are how different actor groups engage in processes of framing, how concepts are being prepared, and by whom and how they are used in planning processes. In turn, this requires reflection on their power structures and underlying rationalities. Spatial planning concepts can be defined as the verbal or visual expression of the envisaged spatial organisation of society (strategic or substantive concept) and the kind of interventions it requires (instrumental or procedural concept) (Dühr, 2007; Zonneveld \& Verwest, 2005). Frequently, spatial concepts are presented as metaphor to make them more memorable and support the communication of the core messages of the concept. Healey (2004) has shown how metaphor is often employed as an aid to either understand place qualities and the spatiality of relations (for example 'the web'), or to focus policy attention and mobilise support ('growth pole', 'clusters', 'compact city'). Metaphors are also used to communicate comprehensive visions for a desirable future of a territory (e.g. 'polycentric development', 'global integration zones'). These three functions of communicating place qualities and spatial relations, to gain political support and to communicate a spatial vision, can also be combined in a single spatial metaphor, for instance 'network' (Healey, 2004).

Some examples of spatial metaphor, such as the 'Blue Banana' (RECLUS, 1989), have been extremely influential in shaping national and European policy discourses. 
The power of spatial concepts and spatial metaphor, as the 'Blue Banana' illustrates, is often to a considerable extent derived from their cartographic visualisation. Spatial concepts therefore frequently rely on simple memorable visual expression because 'without such maps, planners and their users would - literally - be unable to convey what is "the truth of the matter" that interests them' (Van Eeten \& Roe, 2000; see also Dühr, 2007).

However, powerful visual expressions rely on 'mappable' concepts. Some substantive spatial concepts are place-based, such as the 'Green Heart', whereas others are more generic and intended to apply to the entire territory. Yet, as explained above, the aspired transition towards a more focused integrating development planning has been accompanied by a stronger emphasis on procedural concepts in Dutch planning that imply governance or procedural principles. Such procedural concepts, as well as some generic substantive concepts, do not lend themselves as easily for cartographic visualisation as place-based concepts do. Visualising spatial concepts, thus, implies an important limitation that is characteristic of all mapping in planning, namely that territorial features and planning policy that are easy to locate and delineate on maps (such as urban areas or transport infrastructure) are more readily depicted than more diverse territories and spatial features, such as rural areas or landscapes (Dühr, 2007). Such 'structural distortion' (Dühr, 2007: 124) in favour of 'mappable' objects implies disadvantages for procedural concepts as well as for areas that are not easily delineated and located and therefore are not 'on the map' and immediately visible in discussions over the future use of space. In Dutch planning, for example, the 'Nota Ruimte' (VROM et al., 2004; VROM et al., 2006: 12) explains for the concept of 'spatial quality' that 'the actual form' this will take 'will be decided on a situation-bysituation basis by the provinces and municipalities'. This demonstrates that such 
complex planning concepts are not easily mapped, but if they are, the "cartographic filter' which favours material objects will inevitably be applied (Dühr, 2007). In their communicative power, the visualization of such planning concepts will thus be focused on certain aspects only, and likely those that are of a place-based nature at the expense of the more generic substantive and the procedural principles that are equally part of such comprehensive planning concepts.

In essence, to what extent power plays unfold along manifestly discursive ways is a matter of context. To understand how this works in practice, we will focus on two dimensions in our case-studies: 'framing' and 'power and resources'. Dutch planning, with its strong reliance on the communication and framing of substantive planning concepts can be seen as an extreme case (see Dühr, 2007). It is nonetheless important to understand the way communication and framing takes place in the context of locally specific strategic, institutional and material conditions and moves. In doing so, our study provides an example for the analysis of how different types of planning concepts (substantive and procedural) are used by different actors groups in communicative planning processes over contested spaces, such as peri-urban areas. Using this framework, the next sections will shed light on the power and rationality of different planning concepts in a peri-urban area in the Western Netherlands with a view to identifying the political and communicative role of planning concepts that are being promoted by different actors groups in bottom-up planning processes. 


\section{The use of spatial concepts in contested peri-urban spaces: 'Land van Wijk en Wouden' and 'Duin, Horst en Weiden'}

The case study areas are situated in the urbanized West of The Netherlands, between the cities of The Hague, Leiden, Zoetermeer and Alphen aan de Rijn (see Figure 1 and Figure 2). They can be described as peri-urban enclaves in a polycentric urban region (Aalbers et al., 2009). The areas are still 'open and green' as a result of effective zoning by municipalities, applying the national spatial concepts of the Green Heart and the Bufferzones since the 1960s (van Rij et al., 2008). Bufferzones and Green Heart overlapped around the village of Stompwijk since their delineation, but because resisting urbanisation was the main goal of both spatial concepts, this overlap did not lead to conflict in a centralized, top-down context. However, decentralisation of planning and 'area-based development' (as described in section 2) changed the picture. Area-based development implied more than landscape conservation; it meant dynamics, projects and initiatives. Bottom-up initiatives were encouraged and civil society groups were being involved in governance processes concerning area development. As a result, different actor groups made proposals for development of our case study areas, from different visions on their future. To communicate these visions, they developed local successors of the national spatial concepts of 'Green Heart' and 'Bufferzone'. These regional place concepts, named 'Land van Wijk en Wouden' (LWW) and 'Duin, Horst en Weide' (DHW), like their predecessors 'Green Heart' and 'Bufferzone', overlap around Stompwijk (see Figure 2). In contrast to the national spatial concepts, the regional place concepts $d o$ compete: for attention, recognition and funds at the provincial level. Because they compete, communicating the visions is of extra importance to the actor groups involved. Therefore, comparison 
and analysis of these cases may be extra helpful to explore the role of place concepts in a context of decentralised planning in The Netherlands.

\section{Land van Wijk en Wouden}

Among the initiators of Land van Wijk en Wouden (LWW), there was a feeling that the area was considered as 'the back side' of the city, nothing more than spare room for development. The initiators felt that the area should instead be appreciated for its qualities. A coalition developed between the environmental cooperative 'Wijk en Wouden' and inhabitants of the villages, notably Zoeterwoude-Dorp (an environmental cooperative is an association of farmers who take agri-environmental measures and interested citizens, see for instance Franks \& McGloin (2007)). The 'rural' municipalities supported the initiative, followed by the 'urban' municipalities, especially Leiden and Zoetermeer. An area committee was set up in 2000, with representatives of the municipalities, the province, the environmental cooperative and some other local organizations. The area committee is assisted by a program office with two municipal officers. In 2001, local and regional government administrators committed themselves to 'preserving and strengthening the identity of the area, to strengthening its functions for the city, and to create a new urban-rural relationship'.

\section{Framing}

The name 'Land van Wijk en Wouden' refers to its rural character, merging the names of the villages (Stompwijk, Zoeterwoude, Hazerswoude). The area more or less coincides with the Western border of the Green Heart (see Figure 1), but this was not intentional. Its delineation is a direct result from the working area of the environmental cooperative 'Wijk en Wouden', which in turn evolved from existing 
networks of dairy farmers. 'Green Heart thinking' is however represented in the coalition through the local Green Heart Great Polder foundation. At one point in time, it was considered whether the area should extend Southwards and include arable fields too, but it was decided that the area should have a clear meadow identity. The rural character is the core of the place concept of LWW. In the discourse behind it, farmers are the ones who shaped the landscape in the past and who are still indispensible in its management. It seeks to raise awareness among urbanites with respect to the unique qualities of the area and its agrarian character, to ensure public and political support for resisting urbanization. This should ensure preservation of space for agriculture and a future for the dairy farms. The importance of the rural identity can be illustrated by the rejection by the area committee of the idea of a 'regional park' label (see the section on DHW). A park label was considered much too urban (interview program officer). While the discourse starts from farmers' interests, it opens up to the interests of city-dwellers, because it is realized that support from 'the city' is needed to secure future farming in this area and a 'license to produce'. The place concept that results from this discourse is one of a clearly recognizable landscape entity with a strong agrarian production identity (meadows for dairy farming, see Figure 3). To win the hearts of the city-dweller, the area is to be made better accessible, among others through public footpaths on farmland. Also, experiencing the area should be made easier, through events, a touristic map and other information. On the website of the area committee, LWW is advertised as 'Special area, rich in nature, water, primal Dutch landscapes and cultural history'.

Figure 3: Land van Wijk en Wouden (www.landvanwijkenwouden.nl) 
As explained before, the Green Heart does not provide much by way of a legally binding status of protection. Such national ambitions were to be applied to local plans and activities, not implemented. Despite the doctrine status of the Green Heart, the border of the Green Heart has over time been repeatedly adjusted to allow for urbanization at its edges (Koomen et al., 2008). The concept of LWW, in recognition of the need for flexible interpretation of the boundaries of such concepts, also heavily depends on communication with the parties involved. Regularly, conferences or meetings are being organized to again raise the support of the responsible governments. This is not easy, since the area is part of six municipalities and three city regions. The province is the only authority that has a say in the developments in the area as a whole. However, according to the program officer, the focus of the province has shifted to other areas where actual reconstruction activities are planned. As a result, the program officer feels that after all these years, he has to defend the right of the initiative and the place concept to exist.

This somewhat disappointing result partly stems from the limited support LWW has managed to muster. South Holland Province gave LWW the status of Priority Area in 2007 (PZH, 2007), which means that certain subsidies can be accessed. However, the Priority Area status did not yet result in actual subsidies and by lack of funds only a part of the envisioned projects could be executed. The idea of a 'green fund' for financing the projects was accepted by the municipalities during a conference in 2006, but few municipalities actually contributed to the fund. Nevertheless, the program office so far realised about $40 \mathrm{~km}$ of public footpaths on farmland, a mountain bike route, information billboards and picnic tables and organised events (the yearly Polder 
Day attracts 4,000-5,000 people). The lack of action by the governments however also resulted in local organizations starting projects of themselves, apart from the area committee.

Summarizing, the place concept of LWW attributes a primarily rural meaning to the peri-urban area, although the recognition of this meaning with the urbanites is strived for. Power is exercised by gaining support from the powerful, in this case the decision-makers at municipal and provincial level. This support is formalised by means of an administrative agreement. The goal is to achieve and maintain a planning status that acknowledges the farmers' 'licence to produce' and prevents further urbanisation while welcoming the urbanites to 'consume' the area. The initiative tries to 'put itself on the map': both literally and in the minds of the public, through events, tourist information and improving the recreational infrastructure. The funds needed for this are raised among the participating governments, with the financial contribution as an expression of commitment. The financial contribution has been a little disappointing, however.

\section{Duin, Horst en Weide}

Duin, Horst en Weide (DHW) is an idea of the municipalities of Wassenaar, Voorschoten and Leidschendam-Voorburg, who work together in the 'Duivenvoorde Pact' (informal cooperation since 2000, administrative agreement April 2004). At first, DHW simply meant a change of names for the Bufferzone Den Haag- LeidenZoetermeer (PvD, 2004). DHW more or less coincides with the Bufferzone, but the Eastern border is still flexible in the development of the concept and in some versions it incorporates a part of Zoeterwoude municipality. 


\section{Framing}

The name reflects the landscape sequence ('dune, horst and meadow'), underlining the diversity of the area. Diversity is as much a characteristic of the landscape as it is of the population. Wassenaar is known for its high-quality living environment, villas and estates. It is the favourite place to live for diplomats, old nobility, well-to-do policy makers and business people who work in The Hague. In contrast, Stompwijk is a village of less well-to-do inhabitants and farmers.

The discourse behind DHW starts from the needs of the city dweller. The alderman of one of the three municipalities (also administrator of The Hague Region) actually described LWW as 'boring': an empty landscape with few possibilities for recreation and leisure activities, that is too far away for urbanites' use (interview 24 Jan 2008). In his opinion, DHW has much more to offer as a result of the diversity of the landscape and its features. He envisions people to cycle 'from Zoetermeer to the sea' through meadows, along windmills, castles, lush estates and through wild dunes. Farming is secondary to the recreational (consumption) value of the landscape in this vision. In fact, without the city dweller defending the landscape, the farmers would lose their right to be in the area and farmland would be urbanised. Farming should therefore serve the needs of the urbanites. Quoting the alderman: 'Urban pressure can only be halted by making the city-dweller responsible for the area. The city-dweller should become an advocate.'

The discourse behind DHW links green space to cultural history, with an emphasis on 'icons' like the rural estates, the Duivenvoorde castle and the windmills of Stompwijk. The area is described as 'a museum full of paintings of Dutch masters' (Bosch Slabbers landschapsarchitecten, 2007). Linking green space with cultural 
history is an attempt to find elements of a regional identity (Aalbers et al., 2009) in order to raise support for preservation with the city-dwellers. There is also an ecological idea behind DHW. The area should be an ecological corridor as well as a recreational corridor. It should facilitate the migration of plants and animals between the dunes and the Green Heart, even as far as the Veluwe (forest area in the centre of the Netherlands) (Bosch Slabbers landschapsarchitecten, 2007). Developments in the area should improve the recreational facilities (such as walking and cycling routes), bridge barriers (such as roads) and remove elements that damage the landscape experience (such as greenhouses). Much attention goes to the Duivenvoorde Corridor. This is the narrowest part of DHW and is 'clogged up' by greenhouses. However, also Duivenvoorde castle is situated in this narrow strip. The plan is to finance the removal of the greenhouses with the development of 'new estates' that have an obligatory amount of publicly accessible green space ('red for green'). This strategy is in line with the Belvédère concept of 'preservation through development' for built heritage and landscape.

\section{Power and resources}

Apart from the three Duivenvoorde municipalities, the concept is strongly supported by the city-regional authority of The Hague Region. Most of DHW is part of The Hague Region. Its bottleneck, the Duivenvoorde Corridor, is however part of the neighbouring region. To the benefit of DHW, the number of governments involved is smaller than in the case of LWW. What also helps, is that it is an initiative from the governments themselves: the attention of the relevant administrators is already guaranteed. Although the concept seems to play a role so far only in policy making, some civil society groups and NGOs are being involved in the development of the 
plans. The city region has limited power and very little budget for planning issues (Aalbers et al., 2009). To create implementation space for itself, The Hague Region applies for funds with its municipalities, the province, the state and European funds such as INTERREG. A program office was started for the day-to-day management of the DHW ideas, similar to the program office for LWW.

DHW has a Bufferzone status and it is a Belvédère area for its heritage value. The dune part of DHW is a Natura 2000 and drinking water reserve. In short, DHW is protected by EU and national regulations because of cultural values, protection of biodiversity, to provide for recreational space, and to provide for drinking water. Still, the need is felt for another status, which is the 'regional park' status. The Hague Region identified DHW as one of the regional parks in its Regional Structure Plan (RSP: THR, 2008). Because the region has no zoning authority, it organised consensus about the RSP with the municipalities, which are to implement the actual zoning (Aalbers et al., 2009). In addition, the region promoted its 'regional park' concept with the province, striving for its acknowledgement in the provincial spatial strategy, an important planning document. In the next section we will return to the question of whether this was successful.

In summary, the place concept of DHW attributes a primarily urban meaning to the peri-urban area with a complex discourse combining cultural heritage, ecology and recreation. The initiating municipalities have zoning authority, but support at provincial level is strived for to achieve recognition of the importance of the area, in order to maintain a special planning status and to get access to funds. The plea for recognition is backed up with an administrative agreement between the municipalities. Maps have been produced to illustrate the ideas of diversity and connection (see 
Figure 4). Ultimately, the municipalities want to prevent further urbanisation of the area and to improve its recreational value. The DHW initiative started as concept development among public administrators. The urbanites themselves are so far hardly involved. The first attempt for involving the public was a photography contest in 2010.

Figure 4 Duin Horst en Weide (Brons, 2010)

\section{Analysis and discussion}

We summarize and compare the case descriptions and their place concepts in the following matrix:

Table 1

We may characterize DHW as an 'urban' concept, developed by urban actors with a mainly urban claim on the peri-urban area. In contrast, LWW is a 'rural' concept, developed by 'rural' actors with a mainly rural claim on the peri-urban area. However, both concepts aim to prevent urbanisation of the area at stake and to involve urbanites in its conservation and promotion. When looking at what the concepts aim to do as their core concern they do not differ much in that they are both seeking to improve the recreational infrastructure. Deliberately, concepts such as Green Heart, Bufferzone, landscape entity and landscape sequence are used to illustrate and 'sell' these visions. It may not be remarkable that governmental actors do this, in a context of Dutch planning history where spatial concepts have always been numerous and part of the standard tool box. However, also farmers and civilians of an environmental 
cooperative use them, in the case of LWW. Maybe the use of place concepts is inclusive and empowering in the sense that they represent a common language by which local initiators can communicate their vision to governmental actors.

Both place concepts build on substantive planning concepts that date from 1958. The 'new' DHW is an 'old' Bufferzone, and LWW is part of the long-standing concept of the 'Green Heart'. In Dutch planning history, these concepts have been icons of successful planning, gaining power over time. They were 'carriers of previous debates and struggles', as discussed above, and their authority was used to develop their regional successors DHW and LWW. For a long time, both concepts had a rather fixed character. However, with the more flexible national planning approach since the 1990s, and the expected termination of Bufferzones in 2009 (which was not carried through in the end), combined with the decentralisation of planning responsibilities, regional actors felt the need to develop their regional variants of the old concepts to ensure sustained protection of the areas. In doing this, they added new elements to the concepts. They introduced discourses connected to local identities, communication strategies aimed at the regional citizens and a fine-grained vision on measures for improving the recreational infrastructure. The results are more flexible and embedded place concepts than the original ones, although they are still quite 'fixed' in the sense that they continue to adhere to the 'anti-sprawl' planning doctrine: urbanisation is regarded as undesirable and to be prevented by strict zoning. For DHW, the procedural concept of 'preservation through development' was included, but more as a funding mechanism to get rid of unwanted buildings and greenhouses than as an invitation for further urbanisation. 
The fact that both place concepts have in parallel evolved, exist and compete, is a sign that the process of decentralisation and transition to more participation in plan-making has been successful in this part of The Netherlands. Local and regional actors, both governmental and non-governmental, felt the need to take initiative and found the discursive space to develop and promote their ideas. When plan-making is no longer directed primarily 'from above', a multitude of initiatives may evolve, with contrasting spatial claims. This makes the governance process more elaborate. Our place concepts have similar interests at their core and no major differences in envisioned spatial layout of the area. The differences between them are thus subtle and concern the framing of the areas (meaning and spatial delineation) and the initiating actors. The competition between the place concepts therefore is not so much about 'competing claims' (Zonneveld \& Verwest, 2005), but about funds, attention and level of acceptance with the public and in politics. The position 'on the map' plays an important role in this competition. This is illustrated by a discussion on the delineation of DHW in 2009, organised by The Hague Region (THR, 2009). South Holland Province presented its draft plans for Provincial Landscapes. DHW lost most of its 'meadow' to LWW in these plans. The Hague Region objected to this, claiming that loosing the 'meadow' part would hinder bridging barriers for recreation, such as the A4 highway. For The Hague Region, loosing the meadow area would mean losing part of the story (discourse).

Although LWW is more institutionalized than DHW, due to its program office, events, projects and its recognition with the public, attention from administrators seems to dwindle and the promised funds are not supplied. DHW, on the other hand, may have a strong administrative coalition between the municipalities and the city region, but lacks support with the province and acquaintance with the general public. 
The province has more power and funds than the city region and the position of the province may be decisive in the competition between the place concepts. In this context, the province's latest spatial strategy $(\mathrm{PZH}, 2010)$ is of great importance. The Province labelled both LWW and DHW as 'Provincial Landscapes'. In provincial landscapes, urbanisation is not allowed, but their recreational qualities are to be developed. There should be perspective for agriculture, combining food production with the delivery of public goods and services. Interestingly, the overlapping part of the place concepts is appointed to LWW, as uniform landscape entity (Figure 5). This decision was prepared by consultation with the administrators of both regions involved in DHW, in which consensus was reached that a larger area would be needed for developing planning strategies than the scale of LWW and DHW and that actions on the ground are more important than delineation of areas. In other words, the province appeased the conflict by upscaling strategy development. In the struggle between the place concepts, at this moment, LWW 'won' the part of the battle about the spatial framing, since the idea of a landscape entity prevailed with the province over the idea of a landscape sequence. However, DHW also gained. Previously, DHW was no priority area, but now it has the same provincial status as LWW.

The place concepts are more than the 'position on the map', as their history has shown, although the formal status of Provincial Landscape is an important step in their institutionalisation. The actors behind the place concepts will continue to develop and promote them. DHW may even continue to use its original spatial framing in its plan-making. DHW may also develop projects and events and may in this way start to compete with LWW for the attention of the public. The future of the place concepts is bound to be one of more variation and contention. 


\section{Conclusions}

In this paper we compared and analysed two competing place concepts for peri-urban areas in The Netherlands. We aimed to explore how place concepts are used to exercise power, to mobilize resources and to frame meaning over the use of periurban areas in the Dutch planning arena. To this end, we analysed the place concepts in the context of the changing Dutch planning culture and practice. Comparison of the cases showed that one (LWW) reflects a more 'rural' view on the peri-urban, while the other (DHW) reflects a more 'urban' view. One was developed bottom-up (LWW), and the other (DHW) in a more 'top-down' fashion. Yet, both concepts have many similarities in the way they exercise power. Both concepts are used with the objective to get a special planning status to protect the green character; to achieve attention, recognition and support with decision-makers and the public; and to generate resources for project implementation. Maps play an important role in communicating the envisioned meaning of the areas. The initiatives use similar instruments, such as an administrative agreement and a project office. The LWW initiative is however much more advanced in communicating with the public, through a website and events. One may wonder why the initiatives did not join forces before the Province more or less 'forced them' by bringing spatial strategy development to a higher scale level. We think that the difference in views about the identity of the periurban area (rural or urban?) was the biggest obstacle for that.

From analysing these cases, we may conclude that the trend towards multi-level governance and decentralisation of planning has not prompted a complete paradigm shift in The Netherlands, at least not as regards the role and use of place concepts. Old 
substantive planning concepts and top-down governance styles are still invoked by regional and local actors that have received and taken up more responsibility in planning. The old spatial concepts of the Green Heart and the Bufferzone are still successful and live on in regional place concepts that have been prepared by regional actors. Accordingly, the doctrine embracing the urban-rural divide lives on, as both place concepts aim to curb urbanisation. Neither of the place concepts under study has sought to transcend this dichotomy in line with the long-standing calls for policy to create new urban-rural relations. In this sense, not much seems to have changed.

This is not the complete picture, however. At the regional level, the old substantive planning concepts have evolved into place concepts with a strong local identity discourse and a 'process' rather than only a spatial objective, incorporating procedural planning concepts like the Belvedere strategy 'preservation through development'. In this way, the place concepts help to bridge planning principles and planning practice 'on the ground' in novel ways. The case of Land van Wijk en Wouden especially shows that non-governmental actors make use of the space that is offered to them in the new context to take part in or even to initiate plan-making. Both initiatives have an orientation towards a pro-active approach of spatial planning through their program, a program office and the active engagement in organising events and interaction with the public. These aspects in the cases illustrate signs of the shift in Dutch planning practice from integrated spatial planning towards integrating development planning, and from command and control towards shared governance.

The use of place concepts therefore illustrates both the failure and success of the intended paradigm shift in Dutch planning. They reflect the old practice of 'master frames' and spatial concepts, but they also empower non-governmental actors in 
taking part in the plan-making process. Localization adds to the mappability and the communicative value of place concepts (Zonneveld \& Verwest, 2005). Place concepts as we have seen in The Hague Region are more flexible and more communicative than the old spatial concepts. Therefore we can expect that they will continue to be used in Dutch planning practice, especially in peri-urban areas, which are still subject of discursive struggles as a result of their 'in-between' position.

\section{Acknowledgements}

The idea for this paper and most of its information came from the case study work on governance and planning strategies in the Integrated Project PLUREL (Peri-Urban Land Use Relationships - Strategies And Sustainability Assessment Tools For UrbanRural Linkages) funded by the European Commission through its $6^{\text {th }}$ Framework, Contract No. 036921. The Netherlands Ministry of Agriculture, Nature and Food Quality (LNV) contributed through Kennisbasis to the writing process of this paper. Figures 1, 2 and 5 were made by Co Onderstal, Alterra Wageningen UR. 
References

AALBERs, C.B.E.M. and VAN DiJK, T. (2007) JAF Remix: analysis framework. A framework for research of spatial planning and governance strategies in Rural-Urban Regions to promote sustainability of rural-urban linkages. PLUREL D3.2.1. Wageningen: Alterra Wageningen UR.

AAlbers, C.B.E.M., VAn DiJK, T., VAN DER JAGT, P.D. and WesterinK, J. (2009) Analysis of regional spatial planning and decision making strategies and their impact on land use in the urban fringe: case study of The Hague region, The Netherlands. PLUREL D3.3.1. Wageningen: Alterra.

BACHTLER, J. and MCMASTER, I. (2008) EU Cohesion policy and the role of the regions: Investigating the influence of structural funds in the new member states Environment and Planning C: Government and Policy 26(2), pp. 398-427.

Bervaes, J. C. A. M., Kuindersma, W. and Onderstal, J. (2002)

Rijksbufferzones; verleden, heden en toekomst. Den Haag, VROM, 2002. Voorstud. vijfde Nota ruimtel. Orden. Reeks 2 Nr. 8, 94 blz.

Bosch SlabBers landschapsarchitecten (2007) Duin, Horst en Weide. Van Rijksbufferzone tot Regiopark. The Hague: Bosch Slabbers landschapsarchitecten.

BRONS (2010) Landschapsontwikkelingsplan Duin, Horst en Weide. De sleutel tot uitvoering. Achtergronddocument. Culemborg: Brons en partners landschapsarchitecten.

Buiss, A. E., Pedroli, B. and Luginb ̃̄1/4HL, Y. (2006) From hiking through farmland to farming in a leisure landscape: Changing social perceptions of the European landscape Landscape Ecology 21(3 SPEC. ISS.), pp. 375-89.

CSD (1999) European Spatial Development Perspective (ESDP): Towards balanced and sustainable development of the territory of the European Union. Brussels, Potsdam: Committee on Spatial Development, Office for Official Publications of the European Communities.

De Roo, G. (2003) Environmental Planning in the Netherlands: Too Good to be True. From Command-and-Control Planning to Shared Governance. Farnham: Ashgate.

DüHR, S. (2007) The Visual Language of Spatial Planning: Exploring Cartographic Representations for Spatial Planning in Europe. London: Routledge.

EZ (1997) Ruimte voor economische dynamiek: Een verkennende analyse van ruimtelijk-economische ontwikkelingen tot 2020. Den Haag: Ministerie van Economische Zaken.

FALudi, A. (2000) The performance of spatial planning Planning Practice and Research 15(4), pp. 299-318.

FALUDI, A. (2001) The application of the European Spatial development perspective: Evidence from the north-west metropolitan area European Planning Studies 9(5), pp. 663-76.

Faludi, A. and Van Der ValK, A. (1994) Rule and Order - Dutch Planning Doctrine in the Twentieth Century. Dordrecht: Kluwer Academic Publishers. 
Flyvbjerg, B. (1998) Rationality and Power. Democracy in Practice. Chicago, London: The University of Chicago Press.

FLYVBJERG, B. and RICHARDSON, T. (2002) In search of the dark side of planning theory., in Allmendinger, P. \& TeWdWr-Jones, M. (Eds) Planning

Futures: New Directions for Planning Theory, pp. 44-62. London and New York: Routledge.

FRANKS, J. R. and MCGLOIN, A. (2007) Joint submissions, output related payments and Environmental Co-operatives: Can the Dutch experience innovate UK agri-environment policy? Journal of Environmental Planning and Management 50(2), pp. 233-56.

Hall, P. (1993) Comments on Dutch Planning, in FALudi, A. (Ed.) Dutch Strategic Planning in International Perspective, Amsterdam: SISWO.

HEALEY, P. (2004) The treatment of space and place in the new strategic spatial planning in Europe International Journal of Urban and Regional Research 28(1), pp. 45-67.

KoOmen, E., DeKKers, J. and VAN DiJK, T. (2008) Open-space preservation in the Netherlands: Planning, practice and prospects Land Use Policy 25(3), pp. 361-77.

LNV (1996) Visie Stadslandschappen. Den Haag: Ministerie van Landbouw, Natuurbeheer en Visserij.

MAstop, H. and FALUDI, A. (1997) Evaluation of strategic plans: The performance principle Environment and Planning B: Planning and Design 24(6), pp. 815-32.

Needham, B. (2005) The new Dutch spatial planning act: Continuity and change in the way in which the Dutch regulate the practice of spatial planning Planning Practice and Research 20(3), pp. 327-40.

Nilsson, K., Sick Nielsen, T. and PAUleit, S. (2008) A plurel approach to periurban areas. Town \& Country Planning (December ), pp. 519-24.

OCW, LNV, VROM and VENW (1999) Nota Belvédère. Beleidsnota over de relatie cultuurhistorie en ruimtelijke inrichting. Den Haag: Ministerie van Onderwijs, Cultuur en Wetenschappen; Ministerie van Landbouw, Natuur en Visserij; Ministerie van Volkshuisvesting, Ruimtelijke Ordening en Milieu; Ministerie van Verkeer en Waterstaat.

PvD (2004) Pact van Duivenvoorde Samenwerkingsconvenant. Wassenaar: Gemeente Leidschendam-Voorburg, Gemeente Voorschoten en Gemeente Wassenaar.

PZH (2007) Doen wat werkt. Contourennota Levend Landschap. Den Haag: Provincie Zuid-Holland.

PZH (2010) Visie op Zuid-Holland. Structuurvisie. Den Haag: Provincie ZuidHolland.

RECLUS (1989) Les villes 'européennes'. Rapport pour la DATAR. Sous la direction de Roger Brunet par Groupement d'Interêt Public. Montpellier: RECLUS.

REIN, M. and ScHÖN, D.A. (1986) Frame-Reflective Policy Discourse Beleidsanalyse (driemaandelijkse publicatie van het Ministerie van Financiën) 4, pp. 418.

REUSELAARS, I. (2003) Belvedere: Preservation of cultural heritage as part of town and country planning in the Netherlands Archaologisches Nachrichtenblatt 8(2), pp. 189-202. 
RICHARDSON, T. (2006) The thin simplifications of European space: Dangerous calculations? Comparative European Politics 4, pp. 203-17.

RIJKSDIENST VOOR HET NATIONALE PLAN (1958) De ontwikkeling van het westen des lands. 's-Gravenhage: Staatsdrukkerij en Uitgeverijbedrijf.

SAlET, W. and WoltJER, J. (2009) New concepts of strategic spatial planning dilemmas in the Dutch Randstad region International Journal of Public Sector Management 22(3), pp. 235-48.

SCHÖN, D.A. and REIN, M. (1994) Frame Reflection. Toward the Resolution of Intractable Policy Controversies. New York: Basic Books.

SpaAns, M. and TRIP, J.J. (2010) Ruimtelijke kwaliteit en rijksbemoeienis Rooilijn 43 (6), pp. 406-11.

THR (2008) Regionaal Structuurplan. Den Haag: Stadsgewest Haaglanden.

THR (2009) Verslag Programmagroep Duin Horst Weide 18 maart 2009. Den Haag: Stadsgewest Haaglanden.

Throgmorton, J. A. (2003) Planning as persuasive storytelling in a geobal-scale web of relationships Planning Theory 2(2), pp. 125-51.

VAN DEN BRINK, M. (2009) Rijkswaterstaat on the horns of a dilemma. PhD thesis at Radboud University Nijmegen. Delft: Eburon.

VAN EETEN, M. and RoE, E. (2000) When fiction conveys truth and authority the Netherlands green heart planning controversy Journal of the American Planning Association 66(1), pp. 58-67.

VAn RiJ, H.E., DEKKERS, J.E.C. and KoOmEn, E. (2008) Analysing the succes of open space preservation in the Netherlands: the Midden-Delfland case Tijdschrift voor Economische en Sociale Geografie 99(1), pp. p.115-25.

VROM (2008) Wet ruimtelijke ordening (WRO). Den Haag: Ministerie van Volkshuisvesting, Ruimtelijke Ordening en Milieu.

VROM, LNV, VENW and EZ (2004) Nota Ruimte - Ruimte voor ontwikkeling. Ministerie van Volksgezondheid, Ruimtelijke Ordening en Milieubeheer, Ministerie van Landbouw, Natuur en Voedselkwaliteit, Ministerie van Verkeer en Waterstaat, Ministerie van Economische Zaken.

VROM, LNV, VENW and EZ (2006) National Spatial Strategy: Creating Space for Development; Summary. The Hague: Ministry of Housing, Spatial Planning and the Environment; Ministry of Agriculture, Nature and Food Quality; Ministry of Transport, Public Works and Water Management; Ministry of Economic Affairs

WISSINK, W. (2000) Ontworpen en ontstaan: een praktijktheoretische analyse van het debat over het provinciale omgevingsbeleid. Den Haag: Sdu Uitgevers.

WolsinK, M. (2003) Reshaping the Dutch planning system: A learning process? Environment and Planning A 35(4), pp. 705-23.

WRR (1998) Ruimtelijke ontwikkelingspolitiek. Den Haag: Sdu Uitgevers.

ZONNEVELD, W. (2005) In search of conceptual modernization: The new Dutch 'national spatial strategy' Journal of Housing and the Built Environment 20(4), pp. 425-43.

Zonneveld, W. and Verwest, F. (2005) Tussen droom en retoriek : de conceptualisering van ruimte in de Nederlandse planning. Den Haag: Ruimtelijk Planbureau. 


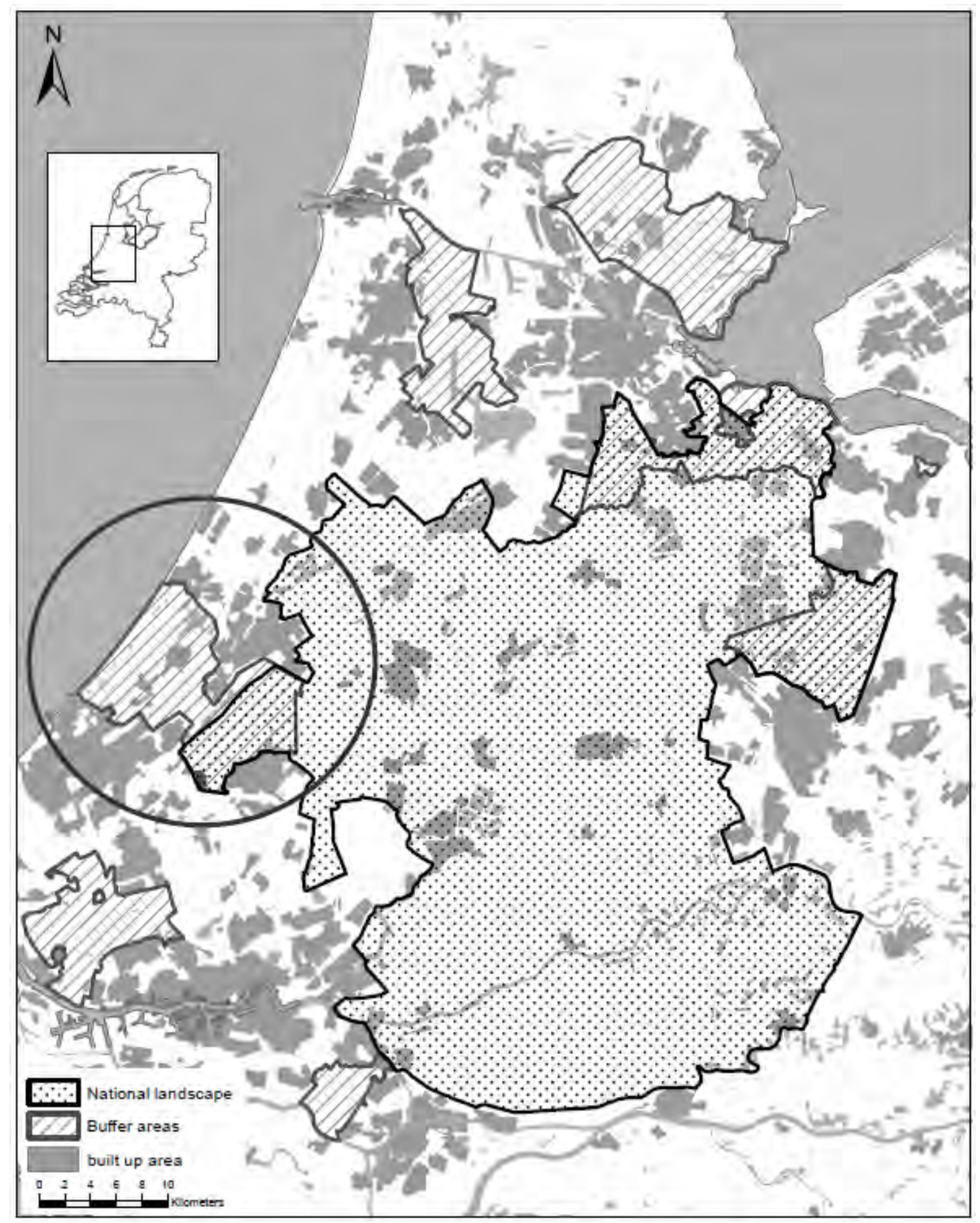

Figure 1: The Green Heart National Landscape and Bufferzones in the urbanized West of The Netherlands, with the location of the case study areas. 


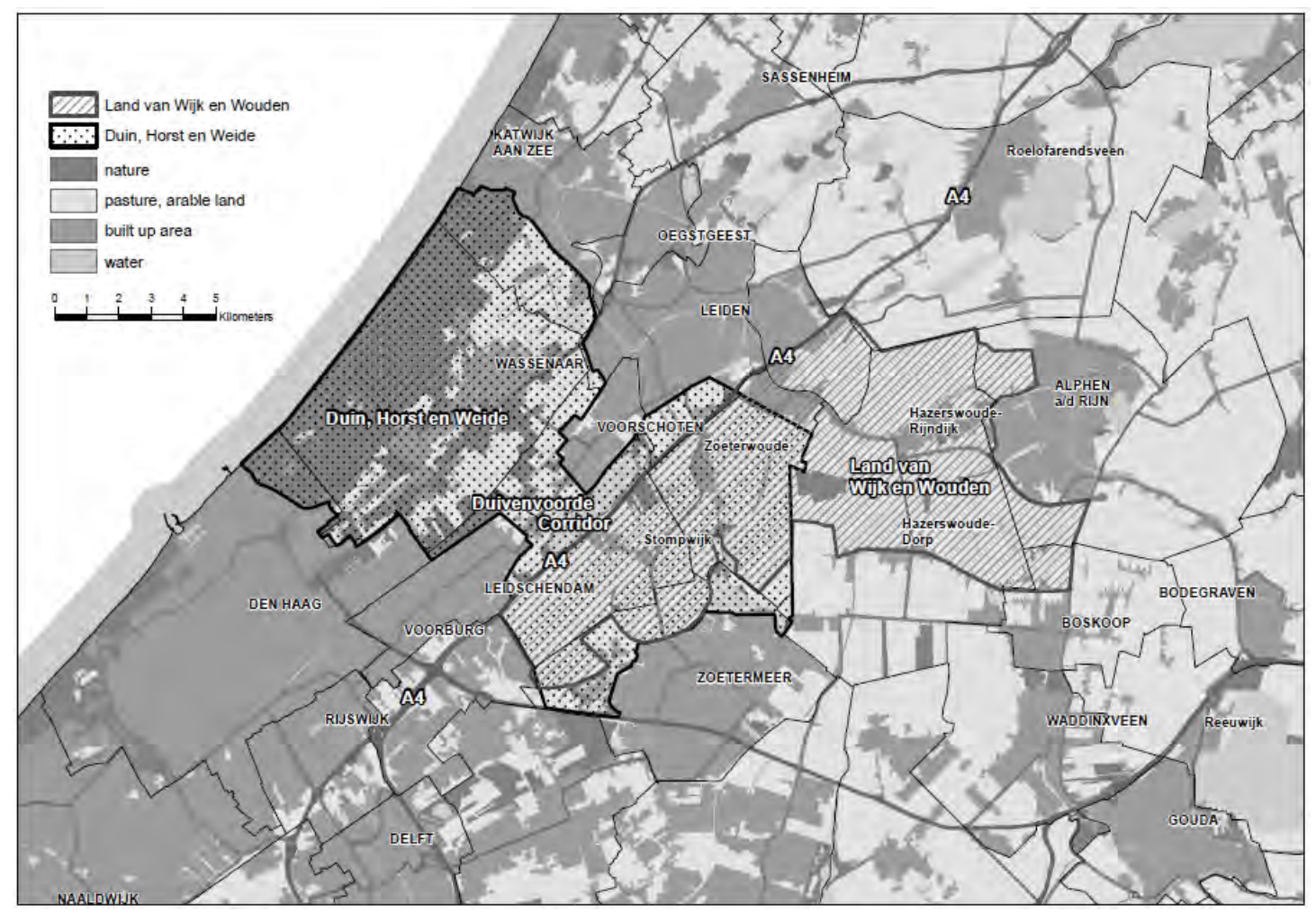

Figure 2: 'Duin, Horst en Weide' and 'Land van Wijk en Wouden' with villages and surrounding cities.

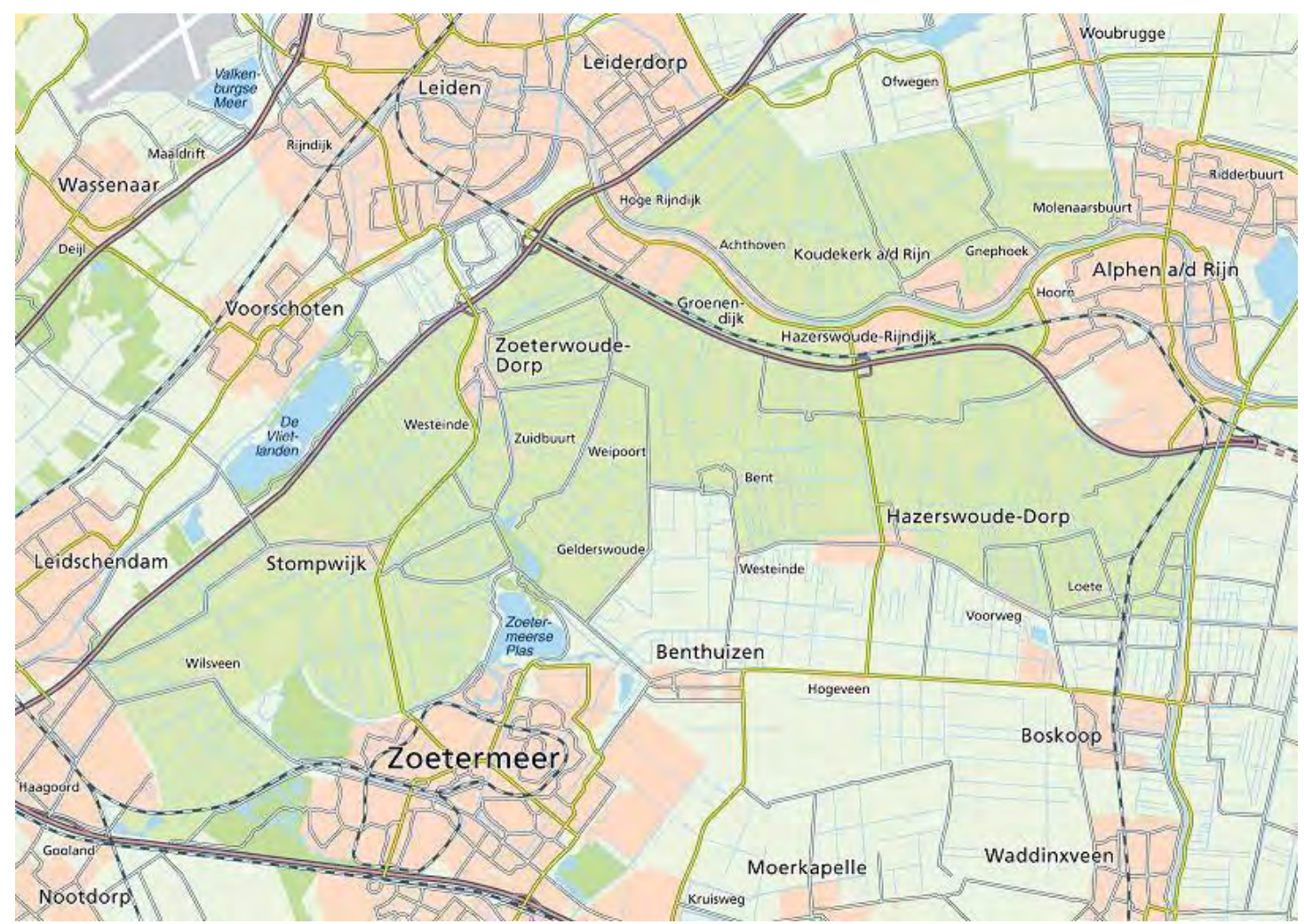

Figure 3: 'Land van Wijk en Wouden' place concept: a uniform meadow area surrounded by cities. Source: area committee Land van Wijk and Wouden 


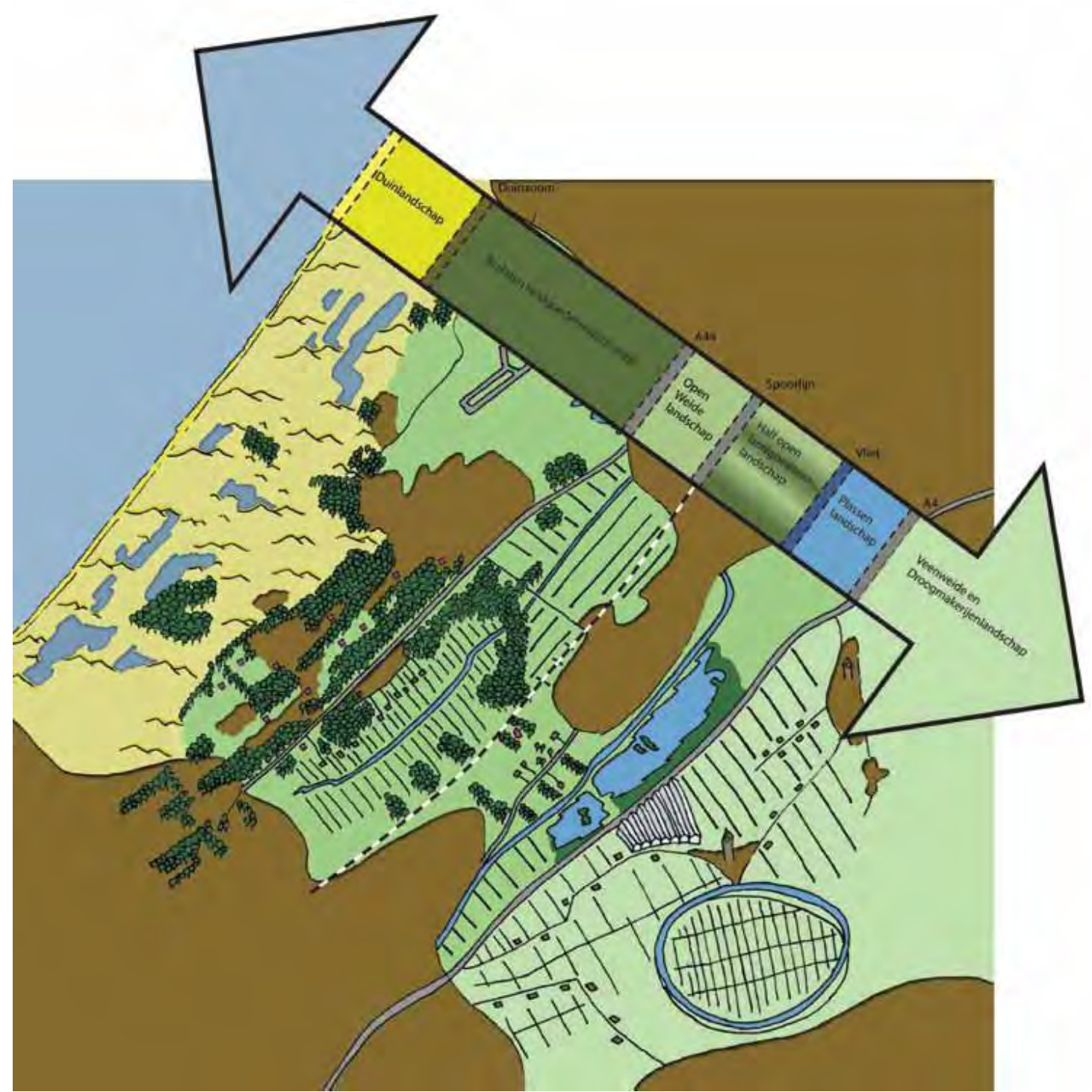

Figure 4: 'Duin, Horst en Weiden' place concept: a sequence of landscapes connecting the coast to the hinterland, with a high potential for recreation. Source: Haaglanden 


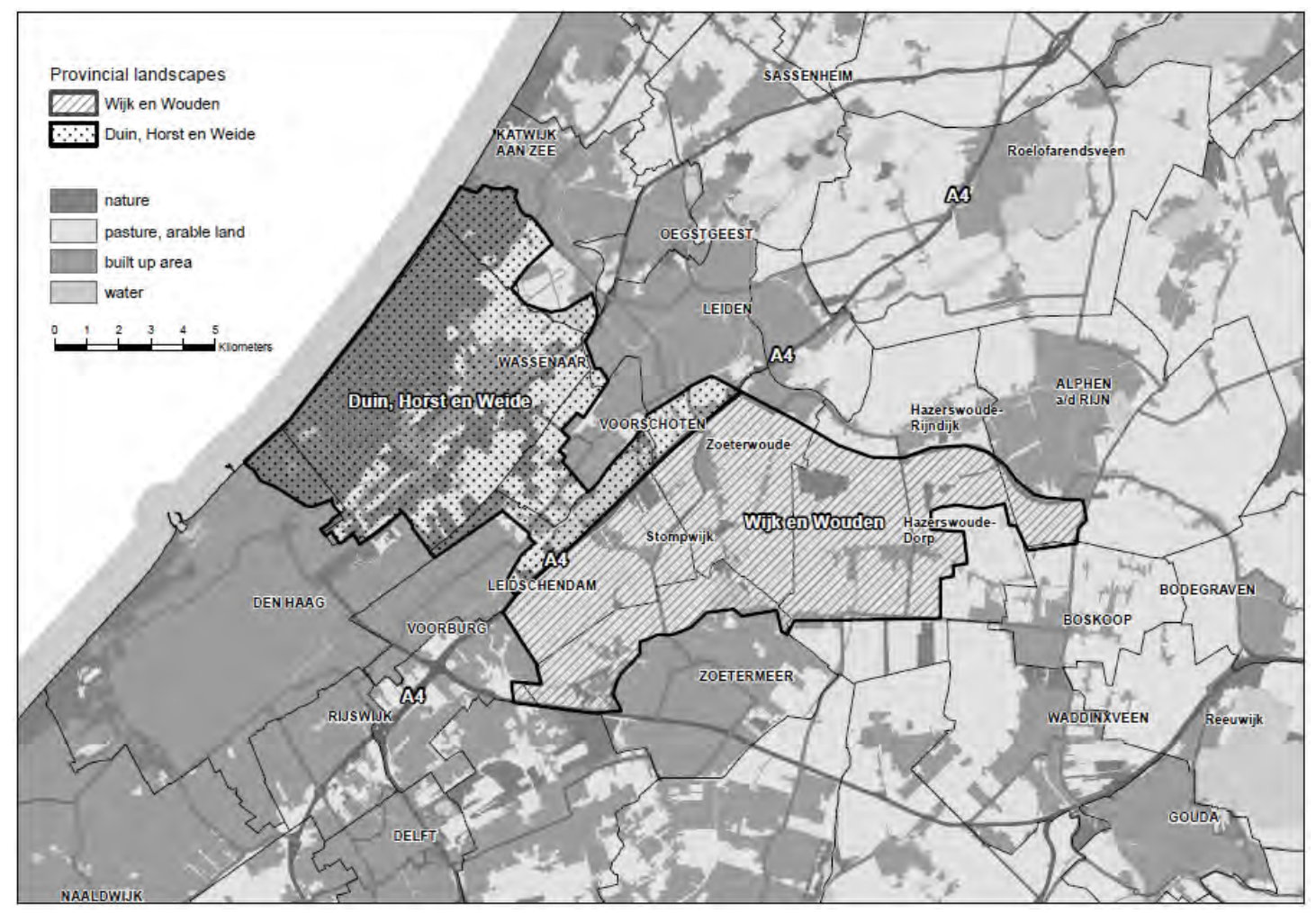

Figure 5: Provincial Landscapes ‘Duin, Horst en Weide' and 'Wijk en Wouden'. 
Table 1: Comparison of 'Land van Wijk en Wouden' and 'Duin, Horst en Weide'

\begin{tabular}{|c|c|c|c|}
\hline & & Land van Wijk en Wouden & Duin, Horst en Weide \\
\hline \multirow[t]{3}{*}{ Frames } & $\begin{array}{l}\text { Discursive } \\
\text { elements }\end{array}$ & $\begin{array}{ll}\text { - } & \text { Peri-urban = rural } \\
\text { - } & \text { Farmers are key } \\
& \text { stakeholders } \\
\text { - } & \text { How can 'urban' support } \\
\text { 'rural? } \\
\text { - Without farmers, the } \\
\text { landscape will disappear } \\
\text { - Production landscape, } \\
\text { where consumers are } \\
\text { welcome }\end{array}$ & 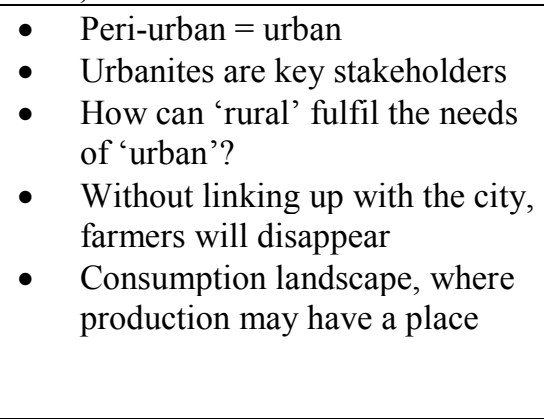 \\
\hline & $\begin{array}{l}\text { Spatial } \\
\text { concepts }\end{array}$ & $\begin{array}{l}\text { - 'Uniform' landscape entity. } \\
\text { - } \quad \text { Agricultural landscape } \\
\text { - Part of the Green Heart }\end{array}$ & $\begin{array}{ll} & \text { Sequence of landscapes } \\
\text { - } & \text { Recreational landscape } \\
\text { - } & \text { Connectivity } \\
\text { - } & \text { Duivenvoorde Corridor } \\
\end{array}$ \\
\hline & Branding & $\begin{array}{l}\text { - } \quad \text { 'Special area, rich in } \\
\text { nature, water, primal Dutch } \\
\text { landscapes and cultural } \\
\text { history' } \\
\text { - Name: after the names of } \\
\text { the villages in the area }\end{array}$ & $\begin{array}{l}\text { - 'A museum full of paintings of } \\
\text { Dutch masters' } \\
\text { - Name: after the landscape types }\end{array}$ \\
\hline \multirow[t]{4}{*}{ Power } & Support & $\begin{array}{l}\text { Concept accepted by } \\
\text { province and participating } \\
\text { municipalities }\end{array}$ & $\begin{array}{l}\text { Concept accepted by city region } \\
\text { and participating municipalities }\end{array}$ \\
\hline & $\begin{array}{l}\text { Governance } \\
\text { style }\end{array}$ & $\begin{array}{l}\text { - Bottom-up, developed by } \\
\text { farmers and small } \\
\text { municipalities }\end{array}$ & $\begin{array}{l}\text { Top-down, developed by public } \\
\text { administrators, but trying to } \\
\text { involve civil society and private } \\
\text { sector. }\end{array}$ \\
\hline & Institutions & $\begin{array}{l}\text { - Within three city regions } \\
\text { - Area committee with } \\
\text { functioning program office }\end{array}$ & $\begin{array}{l}\text { Mainly in one city region, } \\
\text { although narrow corridor in } \\
\text { neighbouring region. } \\
\text { - Administrator The Hague Region } \\
\text { is also alderman in one of the } \\
\text { DHW municipalities. } \\
\text { - Program office to be opened. }\end{array}$ \\
\hline & Status & $\begin{array}{ll}- & \text { Green Heart } \\
\text { - } & \text { Belvedere (Stompwijk) } \\
\text { - } & \text { Wijk en Wouden } \\
& \text { agreement } \\
\text { - } & \text { Provincial Priority area } \\
\text { - } & \text { Provincial Landscape }\end{array}$ & $\begin{array}{ll}\text { - } & \text { National Bufferzone } \\
\text { - } & \text { Belvedere } \\
\text { - } & \text { Natura } 2000 \text { (dunes) } \\
\text { - } & \text { Ruivenvoorde Pact } \\
\text { - } & \text { Provincial Park } \\
\end{array}$ \\
\hline Resources & Finances & 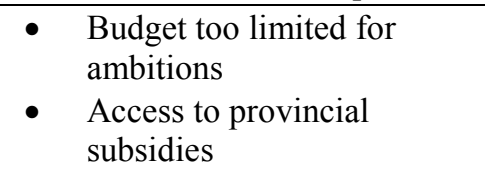 & $\begin{array}{l}\text { - Access to European and central } \\
\text { government funds } \\
\text { - 'Red for Green' projects }\end{array}$ \\
\hline
\end{tabular}

